\title{
IGF2 expression in blood is not associated with its imprinting status in healthy pregnant Chinese women
}

\author{
Ru-Fei Gao' ${ }^{1}$ Xue-Qing Liu' ${ }^{1}$, Ying-Xiong Wang ${ }^{1}$, Xue-Mei Chen ${ }^{1}$, Yu-Bin Ding ${ }^{1}$, Jun-Lin He${ }^{1}$ \\ 1. Department of Reproductive Biology, Chongqing Medical University, Chongqing, China.
}

\begin{abstract}
Loss of Imprinting (LOI) of IGF2 and over-expressed IGF2 are associated with tumorigenesis. Our previous epidemiological study found a relatively high frequency of IGF2 LOI in healthy mid-gestation pregnant women. The aim of this study is to determine whether the expression of IGF2 is associated with its imprinting status in healthy Chinese pregnant women. The IGF2 imprinting status of 300 pregnant women was analyzed. 20 cases of IGF2 LOI and 20 cases of IGF2 retention of imprinting (ROI) were selected randomly for IGF2 expression analysis. The expression pattern of IGF2 between the group with IGF2 ROI and group with IGF2 LOI in healthy Chinese pregnant women was evaluated by real time PCR and western blot. The result showed no significant differences between IGF2 ROI and LOI groups in mRNA and protein levels. These results imply that IGF2 imprinting status has no obvious impact on its expression. There may be some unknown important factors other than imprinting status driving IGF2 expression.
\end{abstract}

Key words: Insulin-like growth factor 2; loss of imprinting; retention of imprinting; pregnancy.

\section{INTRODUCTION}

Genomic imprinting is a common mechanism by which a gene is preferentially expressed based on the parental origin of the allele (Byun et al. 2007). Insulin-like growth factor 2 (IGF2), located at $11 \mathrm{p} 15.5$, has been known as a maternally imprinted and paternally expressed gene in most human tissues (Vu \& Hoffman 1994). It plays a fundamental role in embryo growth, differentiation and placental development (Birnbacher et al. 1998; Constancia et al. 2002; Naeve et al. 2000; Wang et al. 1994). Studies have demonstrated that the IGF2 LOI gene is associated with the tumorigenesis of different types of cancers (Byun et al. 2007; Cui et al. 2002; Fu et al. 2008; Honda et al. 2008). $67-77 \%$ of IGF2 LOI was observed in sporadic Wilms' tumor cases (Ogawa et al. 1993), 47\% in adult lung cancer (Suzuki et al. 1994), 86\% in rhabdomyosarcoma (Zhan et al. 1994) and high incidence of LOI of IGF2 in other tumors including testicular germ cell tumors (van Gurp et al. 1994), choriocarcinoma (Hashimoto et al. 1995), bladder cancer (Byun et al. 2007) and colorectal tumors (Cui et al. 2003).

However, recent studies revealed that IGF2 LOI was not a phenomenon specific to cancer, it may occur in normal tissues such as normal cervical tissues adjacent to cervical cancers (Douc-Rasy et al. 1996) and noncancerous liver specimens around hepatocellular carcinomas (Takeda et al. 1996). In the human fetal liver IGF2 appeared to be imprinted, while relaxing its imprinting in the second half of the $1^{\text {st }}$ year of postnatal life (Davies 1994); LOI remained in the adult liver (Kalscheuer et al. 1993). An epidemiological study also showed that IGF2 LOI is found in the cord blood of newborns (Dai et al. 2007).

In theory, IGF2 LOI would lead to a doubling of IGF2 mRNA abundance and a 2-fold increase in IGF2 production (Vu et al.). However, mixed results were shown on the relationship between IGF2 expression and its imprinting status. Wu et al. (1997) found that LOI had strong association with IGF2 overexpression and played an important role in carcinogenesis of cancers. IGF2 LOI also resulted in overexpression of IGF2 in childhood tumors (Muller et al. 2000; Ogawa et al. 1993; Roy et al. 2000). Micha et al. (1999) observed that none of the pancreatic tissues with IGF2 LOI showed concomitant overexpression of IGF2 transcripts. The LOI of IGF2 may induce both increased or decrease expression, which could initiate the onset of Wilms' tumor (Yun 1998). Wang et al. (1996) reported that increased expression of the IGF2 gene in Wilms' tumor did not depend on loss of genomic imprinting or loss of heterozygosity. In prostate cancer, IGF2 imprinting correlated with IGF2 expression in tissues associated with the tumor, but not within the tumor foci (Bhusari et al.). In addition, no association of IGF2 LOI with increased expression of IGF2 mRNA was observed in Ewing's sarcoma (Zhan et al. 1995). Waterland et al. (2006) revealed that a folate-deficient diet caused significant IGF2 LOI in mice offspring and IGF2 expression was significantly reduced in the treatment group. And LOI patterns have no direct influence on altered expression levels of imprinted genes on growth in adult mouse hybrids (Shi et al. 2005). These studies indicated that LOI may not be always involved in the regulation of IGF2 expression and some other unknown factors may be driving IGF2 expression.

To obtain a better understanding of the relationship between IGF2 expression and the imprinting status of IGF2, peripheral blood of healthy pregnant women was evaluated by screening the expression and imprinting status of IGF2. Here we examine the correlation of LOI and IGF2 expression in pregnant women.

\section{MATERIALS AND METHODS}

Sample Collection

All the peripheral blood samples $(\mathrm{n}=300)$ chosen for our study were obtained from healthy pregnant women aged 20 to 30 
years who visited the First and the Second Affiliated Hospital of Chongqing Medical University in the period from February 2008 to August 2009. The research was approved by Local Ethics Committee and informed written consent was obtained from all participants. With clinical examination and ultrasound examination, the gestation $(20.6 \pm 1.2$ weeks $)$ was calculated. The subjects who had a history of gastrointestinal disease or major pregnancy complications were excluded. The pregnancy process and pregnancy outcome were followed up till the children were born.

With standard procedures, fasting blood samples were obtained into EDTA-containing vacuum tubes and $0.5 \mathrm{ml}$ peripheral blood was frozen at $-20^{\circ} \mathrm{C}$ for DNA and protein extraction. The separated lymphocytes were used for RNA extraction.

\section{DNA extraction}

Genomic DNA was extracted using a TIANamp Blood DNA Kit (TIANGEN Biotechnology Co. Ltd, Beijing, China) according to the manufacturer's instructions and the extracted DNA was stored at $-20^{\circ} \mathrm{C}$ for genotyping analysis.

cDNA synthesis

Total RNA extraction was performed using Trizol reagent (Invitrogen Corporation, USA). Quantification and purity were assessed by optical density (OD) measurement at $260 \mathrm{~nm}$ and $280 \mathrm{~nm}$. Integrity of the total RNA was examined by agarose gel electrophoresis and stored at $-20^{\circ} \mathrm{C}$. The reverse transcription of cDNA was performed with $0.5 \mu \mathrm{g}$ of total RNA in a $10 \mu \mathrm{l}$ reaction using the First Strand synthesis for RT-PCR kit (TAKARA Biotechnology Co. Ltd, Dalian, China). cDNA was stored at $-80{ }^{\circ} \mathrm{C}$ for analysis of IGF2 LOI and ROI and Realtime PCR.

\section{Analysis of IGF2 LOI and ROI}

To identify heterozygous cases for imprinting analysis, polymorphic pattern of genomic DNA was examined by ApaI polymorphism of axon 9 for IGF2. Cases heterozygous for IGF2 were further analyzed with PCR products of the first stand cDNA as described and for the analysis of imprinting status. The 236bp RT-PCR products (Fig. 1 A) of the IGF2 gene were digested with ApaI endonuclease, followed by electrophoresis on 3\% Biowest agarose gel. The digestion products showing both $236 \mathrm{bp}$ and $173 \mathrm{bp}$ fragments are indicative of LOI and retention of IGF2 imprinting (ROI) (Fig. $1 \mathrm{~B}$ ). All the protocols were described in our previous study (Gao et al. 2011).

\section{Real-time PCR of IGF2 mRNA expression between LOI and ROI}

All Real-time PCR were performed using SYBR Premix Ex Taq (TAKARA Biotechnology Co. Ltd, Dalian, China) and a Light Cycler (Bio-Rad $\mathrm{iQ}^{\mathrm{TM}} 5$ Muliticolor Realtime PCR detection system). Briefly, $2 \mu 1$ of aliquots containing cDNA were amplified in a total volume of $20 \mu \mathrm{l}$ containing $4 \mu \mathrm{l}$ of a $5 \times$ SYBR PreMix Ex Taq and $0.2 \mu \mathrm{M}$ of each primer. For internal controls, glyceraldehyde-3phosphate dehydrogenase (GAPDH) was also amplified. The following specific primers for IGF2 and GAPDH were used: IGF2 (forward: 5'-CACGCCAAACACTGAAT-3', reverse,
5'-GCAAGCGTTACAAGGTTA-3', product size: 142bp), GAPDH (forward: 5'-CTCTCTGCTCCTCCTGTTCGACAG-3', reverse, 5'-GTGGAATCATATTGGAACATGT-3', product size: 230bp) (Sangon Biological Engineering Technology \& Services Co. Ltd, Shanghai, China). All samples were run in triplicate. For appropriate negative controls, the RNA template was replaced with nuclease-free water in each run. Melting curves of the products were obtained after cycling with a stepwise increase of temperature from $55^{\circ} \mathrm{C}$ to $95{ }^{\circ} \mathrm{C}$. At the end of 40 cycles, reaction products were separated electrophoretically on an agarose gel and stained with ethidium bromide for visual confirmation of the PCR products. Relative gene expression levels were calculated with the $2^{-\Delta \Delta C T}$ method.

\section{Western blotting analysis}

The total protein concentration of plasma samples was evaluated using the Bradford assay. Equal amounts $(30 \mu \mathrm{g}$ per lane) of diluted plasma samples were incubated in SDSPAGE sample buffer, subjected to SDS-PAGE analysis with $12 \%$ acrylamide gel, and then electrophoretically transferred onto a polyvinylidene difluoride (PVDF) membrane (Bio-Rad, USA). The membrane was subsequently blocked in 5\% skim milk powder in $0.1 \%$ Tris-buffered saline/Tween-20 and then incubated with rabbit polyclonal to IGF2 primary antibody (Abcam, Cambridge, MA, USA) followed by incubation with the appropriate secondary antibody of peroxidase-conjugated goat anti-rabbit IgG (Zhongshan Goldenbridge Biotechnology Co., Ltd, Beijing, China). Immuno-reactive proteins were visualized by a chemiluminescence reaction using the ECL Western blocking detection system (Amersham).

\section{Bisulfite genomic sequencing for methylation analysis}

The IGF2 DMR0 region (GenBank nucleotides 631-859, accession No. Y13633) has been previously reported to be hypomethylated in colorectal cancers with LOI at IGF2 (Cui et al. 2002). In this study, the methylation status of this region was quantified in normal pregnancy via BSP. Genomic DNA extracted from peripheral blood was treated with sodium bisulfite using EZ DNA Methylation-Gold kit according to the manufacturer's instructions. Each PCR

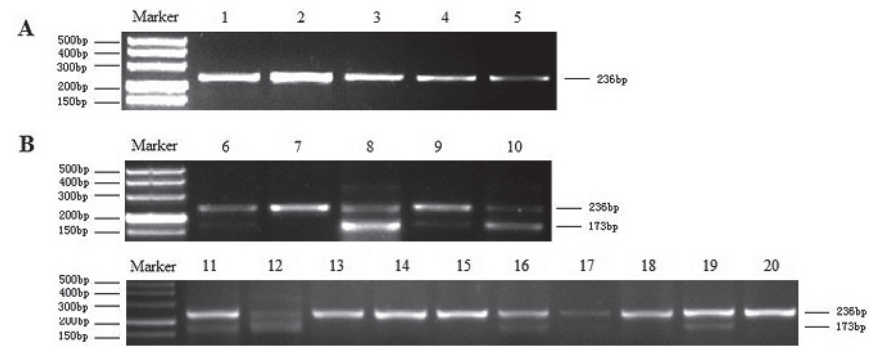

Figure 1. Analysis of IGF2 LOI and ROI in pregnancy. A. $2 \mu \mathrm{l}$ CDNA of the heterozygote informative cases was amplified by RTPCR. B. In each case of IGF2, the RT-PCR product was digested with 20 units of $\mathrm{Apal}$ endonuclease. The presence of a 236bp fragment indicates an IGF2 ROI case and the presence of both the $236 \mathrm{bp}$ and $173 \mathrm{bp}$ fragments indicates an IGF2 LOI case. Lanes 7, $13-15,18,20$ are the cases of IGF2 ROI. Lanes 6, 8-12, 16, 17, 19 are the representative cases of IGF2 LOI. 
mix reaction contained 10 pmol of the forward primer (5'-TAGGGTGGTGTTTGTGGGGA-3'), 10 pmol of the reverse primer (5'- AAAACTTCCCRATACTAATAAAAAAACC -3'), 3 $\mu \mathrm{l}$ of bisulfite-modified DNA, $1 \mu \mathrm{l}$ of $10 \mathrm{pmol} / \mu \mathrm{l}$ primers, $1 \mu \mathrm{l}$ of $10 \mathrm{mmol} / \mathrm{L}$ dNTP, $5 \mu \mathrm{l}$ of $10 \times$ PCR buffer, $0.8 \mu \mathrm{l}$ of HotStart Taq DNA polymerase (Takara). PCR amplification conditions were as follows: initial denaturation at $98{ }^{\circ} \mathrm{C}$ for $5 \mathrm{~min}$; 40 cycles of $45 \mathrm{sec}$ at $94{ }^{\circ} \mathrm{C}, 45 \mathrm{sec}$ at $56{ }^{\circ} \mathrm{C}$, and $1 \mathrm{~min}$ at $72{ }^{\circ} \mathrm{C}$; followed by a final extension at $72{ }^{\circ} \mathrm{C}$ for $10 \mathrm{~min}$. Products purified with the Universal DNA Purification kit (Tiangen, Beijing, China) were cloned into pUC18-T and transformed into chemically induced competent E. coli. Five insert-positive clones of each sample were chosen for sequencing by the Sangon company.

Statistical analysis

All statistical analyses were carried out using SAS for WINDOWS software (version 8.2; SAS Institute Inc, Cary, NC). Data are presented as the means \pm S.D. Differences in IGF2 mRNA and protein levels between IGF2 LOI and ROI were compared using Student's $t$ test. The relationship between the expression and the imprinting status of IGF2 was examined with logistic regression models. $\mathrm{P}<0.05$ was considered to indicate statistical significance.

\section{RESULTS}

For the ApaI polymorphism site in exon 9 of IGF2, the unrestricted PCR product (AA genotype) has a size of $236 \mathrm{bp}$, and complete restriction (GG genotype) generates bands of $173 \mathrm{bp}$ and $63 \mathrm{bp}$. Samples with $236 \mathrm{bp}$ and $173 \mathrm{bp}$ fragments were heterozygotes (AG genotype), which made them informative for further analysis of imprinting status (Figure.1). Of the 300 women analyzed, $164(54.67 \%)$ cases were heterozygous with the AG genotype and informative for imprinting status analysis of IGF2. Of the 164 cases analyzed for imprinting status, $44(26.83 \%)$ were IGF2 LOI cases while $120(73.17 \%)$ were IGF2 ROI. The IGF2 DMR0 region has been previously reported to be hypomethylated in colorectal cancers with LOI at IGF2 (Cui et al. 2002). Our BSP results showed that, except for $\mathrm{CpG} 2$, all the $\mathrm{CpG}$ sits in this region were also hypomethylated in blood lymphocytes in normal pregnancy with IGF2 LOI (Figure. 2).

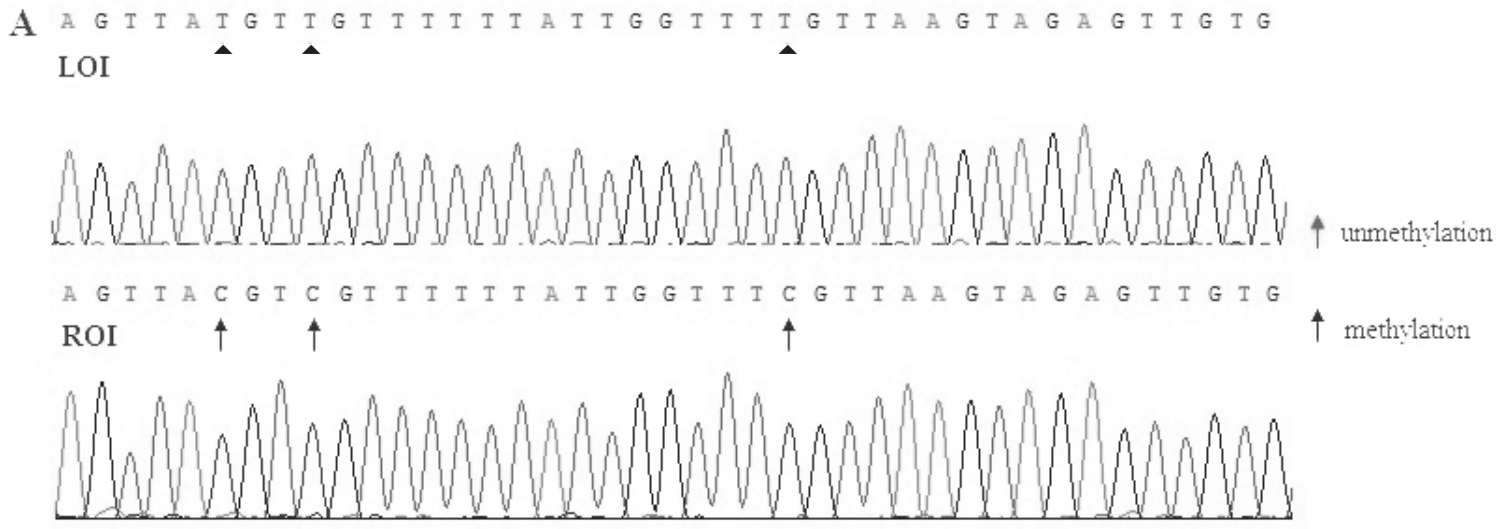

B

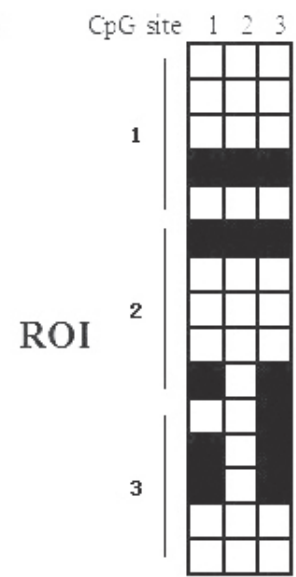

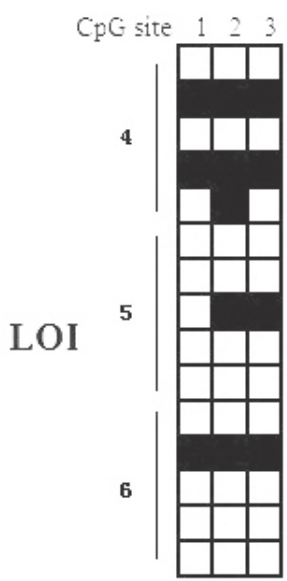

$\mathrm{C}$

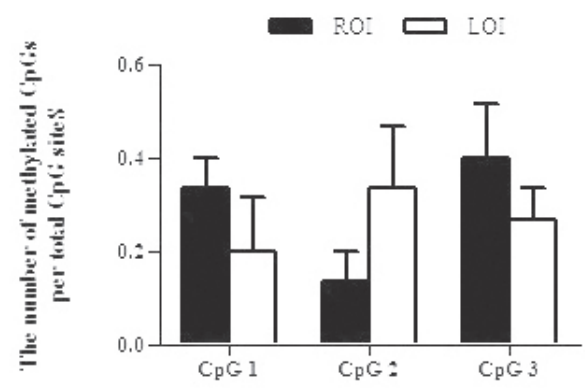

Figure 2. Bisulfite sequencing of IGF2 DMRO region. Representative sequences of the IGF2 DMRO region (GenBank nucleotides 631-859, accession No. Y13633) in the ROI group and LOI group. Methylated CPG sites are indicated by black arrows and non-methylated $C P G$ sites by arrow heads. B. The methylation status at each of $3 \mathrm{CpGs}$. The white squares represent non-methylated CpGs, and the black squares represent methylated CpGs. Samples are marked by numbers. Each line represents one clone. $C$. The bar chart shows the average number of methylated $\mathrm{CpGs}$ per $\mathrm{CPG}$ site according to the BSP results. Except for CpG 2, all the CpG sites in this region were hypomethylated in blood lymphocytes with IGF2 LOI $(P<0.05)$. 
20 cases of IGF2 LOI and 20 cases of IGF2 ROI were selected randomly for further analysis. The general characteristics of subjects with IGF2 LOI and IGF2 ROI are presented in Table 1 . The mean age was $25.3 \pm 4.2$ years in the group with ROI and $24.2 \pm 2.8$ years in the group with LOI. The mean gestational age at enrollment was $20.9 \pm 1.5$ weeks in the group with ROI and $20.6 \pm 1.7$ weeks in the group with LOI. $5.7 \%$ of the group with ROI and $6.1 \%$ of the group with LOI took antibiotic medicine for a cold during pregnancy. $3.9 \%$ of the group with ROI and $4.0 \%$ of the group with LOI had bad habits such as smoking and drinking alcohol which could be harmful to embryo development. None of the subjects had complications related to pregnancy. No obvious difference was found in the general characteristics between LOI and ROI.

Expression of IGF2 mRNA was detected by Real-time PCR. The amplification curve and melt curve for Real-time PCR are shown in Fig. $3 \mathrm{~A}$ and Fig. 3B, respectively. The relative amounts of IGF2 mRNA (IGF2/GAPDH mRNA) in blood lymphocytes in normal pregnancy are shown in Fig. 3C. The IGF2 mRNA level in the group with LOI was a little lower than in the group with ROI, but the difference between the group with ROI and LOI was not significant $(\mathrm{P}=0.281)$.

The protein level of IGF2 in different groups with ROI and LOI in plasma was detected by western blot (Figure 4). The IGF2 protein expression was associated with mRNA expression. Densitometric analysis revealed that there was no difference of IGF2 protein expression between the two groups $(\mathrm{P}=0.275)$. This showed that there was not a close correlation between the mRNA $(\mathrm{OR}=1.401, \mathrm{P}=0.290)$ and protein $(\mathrm{OR}=1.418, \mathrm{P}=0.284)$ expression and the imprinting status of IGF2. Pregnancy outcome was followed up, and no birth defects were found in the two groups.

\section{DISCUSSION}

The frequency of IGF2 LOI, which ranges from $12 \%$ to $100 \%$ in various tumors, suggested that aberrant imprinting is an important epigenetic cause of human carcinogenesis. However, a relatively high frequency of IGF2 LOI was also found in normal human tissue including human fetal liver in the second half of the 1st year of postnatal life (Davies 1994) and the cord blood of newborns (Dai et al. 2007). In our previous epidemiological study, $14.67 \%(44 / 300)$ of pregnant women showed IGF2 LOI. These results indicated that IGF2 LOI is not tumor specific and may be required in some normal biological processes. The association of IGF2 LOI and IGF2 expression in

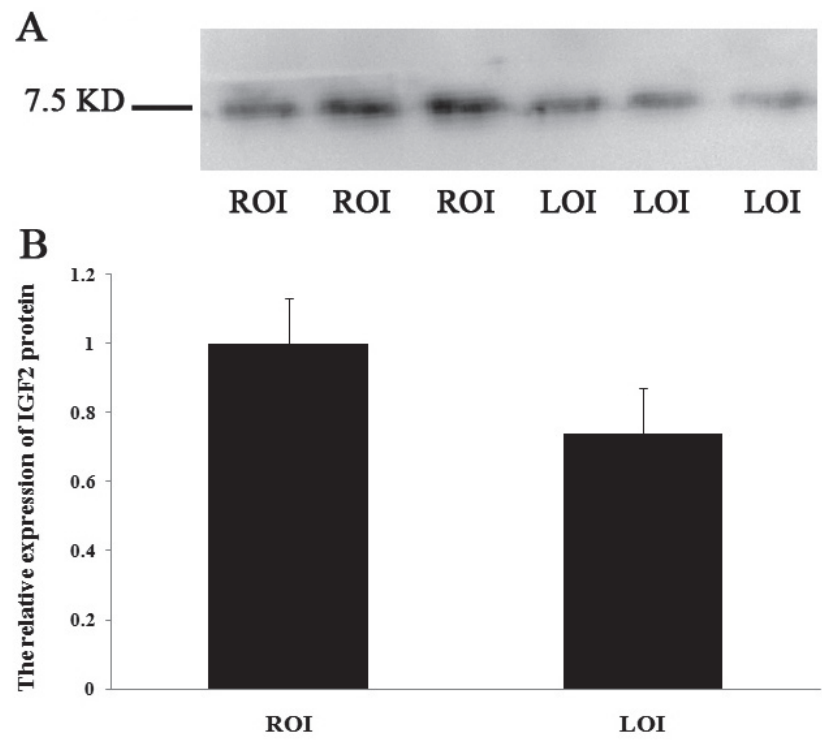

Figure 4. Western blot analysis of IGF2 protein expression in groups with LOI and ROI. Total protein was extracted from plasma samples of the subjects with IGF2 ROI and LOI. Protein level of IGF2 in the two groups was analyzed by western blot. As control for equal protein loading in western blot analysis, the membrane was re-stained with Ponceau. A, IGF2 protein expression in representative cases. $B$, Densitometric analysis of the western blot.
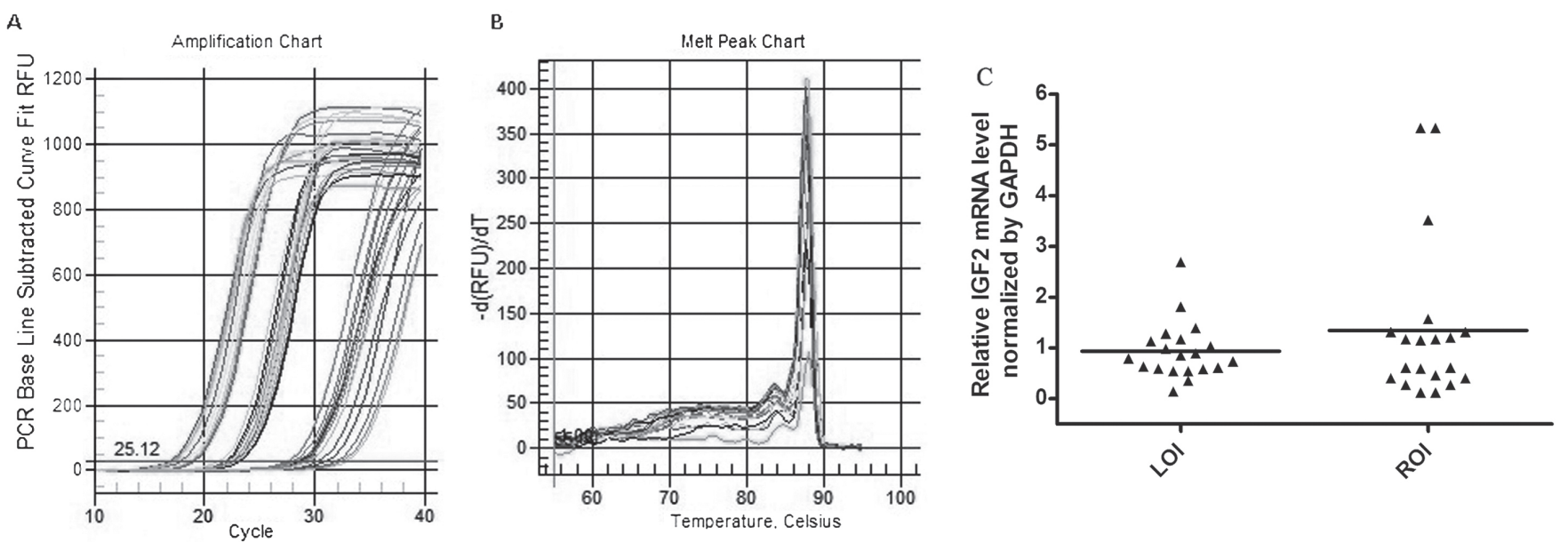

Figure 3. Real time PCR analysis of IGF2 mRNA expression in groups with LOI and ROI. Total RNA isolated from heterozygous with AG genotype was subjected to real-time PCR. A. Amplification chart. B. melt peak chart. C. Relative mRNA expression of IGF2 was calculated (normalized by GAPDH) and plotted in the graph. The ROI IGF2 mRNA level was set as control. Data are presented as mean \pm S.D. The difference of IGF2 mRNA levels between IGF2 LOI and ROI groups was compared using Student's $t$ test $(P=0.281)$. The horizontal line represents the mean value of each group. 
TABLE 1

General characteristics of the subjects

\begin{tabular}{cccc}
\hline Variables & ROI $(\mathrm{n}=20)$ & LOI $(\mathrm{n}=20)$ & P value \\
\hline Age of gestation & $25.3 \pm 4.2$ & $24.2 \pm 2.8$ & 0.693 \\
Weeks of gestation at survey & $20.9 \pm 1.5$ & $20.6 \pm 1.7$ & 0.782 \\
Times of gestation & $1-4$ & $1-4$ & 0.887 \\
Times of birth & $0-3$ & $0-3$ & 0.856 \\
Smoking & $1.9 \%$ & $2.2 \%$ & 0.643 \\
Drinking & $2 \%$ & $1.8 \%$ & 0.748 \\
Medicine & $5.7 \%$ & $6.1 \%$ & 0.720 \\
\hline
\end{tabular}

tumor tissues has been demonstrated in several clinical and animal studies, although the results were mixed. Some studies showed that IGF2 overexpression in mRNA was associated with IGF2 LOI in various tumors (Hajdu et al.; MartinTrujillo et al.; Xu et al. 2006). However, some other studies also showed that IGF2 overexpression was not dependent on loss of genomic imprinting or loss of heterozygosity (Bhusari et al. ; Wang et al. 1996; Zhan et al. 1995). Some researchers demonstrated that IGF2 LOI was associated with decreased expression of IGF2 (Shi et al. 2005; Waterland et al. 2006). In our study, the IGF2 expression was evaluated in order to find out whether LOI had effects on IGF2 expression in midgestation pregnant women. We found that the IGF2 mRNA level in the group with LOI was a little lower than in the group with ROI in peripheral blood lymphocyte of normal pregnancy. But there was no significant difference between the group with ROI and LOI. These results suggest that some unknown factors other than LOI might drive the expression of IGF2.

Although the precise effect of IGF2 LOI on biological processes is not clear, LOI has been demonstrated to be associated with increased cellular proliferation and therefore plays a role in tumorogenesis (Byun et al. 2007; Cui et al. 2003; Hashimoto et al. 1995; Kaneda et al. 2007; Suzuki et al. 1994; van Gurp et al. 1994; Zhan et al. 1994). Little is known of the importance of IGF2 in adults, except the brain and liver, where there is biallelic expression of IGF2. In this study, the followup analysis of pregnant outcome showed no obvious harmful effects on offspring in the IFG2 LOI group (data not shown). The imprinting status of IGF2 in fetus and placenta would be more important to produce an effect on pregnancy and offspring. It may indicate that IGF2 LOI might be a common phenomenon in mid-gestation pregnant women, or it might be a salvage pathway for some unknown bad effects of pregnancy. This may also give us a clue to explain why frequent IGF2 LOI is found in some persons who do not suffer from a disease such as cancer.

\section{ACKNOWLEDGEMENTS}

This research was supported by the National Natural Science foundation of China (No.30700898); Chongqing Population and Family Planning Commission (No.2007-1-002); Chongqing Education Commission (No. kj090313); Natural Science Foundation Project of CQ CSTC (No.cstc2009BA5082, 2009BB5271, 2011JJA10085); Excellent Doctoral Dissertation of Chongqing Medical University.

\section{REFERENCES}

BHUSARI S, YANG B, KUECK J, HUANG W, JARRARD DF. (2011) Insulinlike growth factor-2 (IGF2) loss of imprinting marks a field defect within human prostates containing cancer. Prostat 71:1621-1630

BIRNBACHER $R$, AMANN $G$, BREITSCHOPF $H$, LASSMANN $H$, SUCHANEK G, HEINZ-ERIAN P. (1998) Cellular localization of insulin-like growth factor II mRNA in the human fetus and the placenta: detection with a digoxigenin-labeled cRNA probe and immunocytochemistry. Pediatr Res 43:614-620

BYUN HM, WONG HL, BIRNSTEIN EA, WOLFF EM, LIANG G, YANG AS. (2007) Examination of IGF2 and H19 loss of imprinting in bladder cancer. Cancer Res 67:10753-10758

CONSTANCIA M, HEMBERGER M, HUGHES I, DEAN W, FERGUSONSMITH A, FUNDELE R, STEWART F, KELSEY G, FOWDEN A, SIBLEY C, REIK W. (2002) Placental-specific IGF-II is a major modulator of placental and fetal growth. Nature 417:945-948

CUI H, CRUZ-CORREA M, GIARDIELLO FM, HUTCHEON DF, KAFONEK DR, BRANDENBURG S, WU Y, HE X, POWE NR, FEINBERG AP. (2003) Loss of IGF2 imprinting: a potential marker of colorectal cancer risk. Science 299:1753-1755

CUI H, ONYANGO P, BRANDENBURG S, WU Y, HSIEH CL, FEINBERG AP. (2002) Loss of imprinting in colorectal cancer linked to hypomethylation of H19 and IGF2. Cancer Res 62:6442-6446

DAI YM, HU YL, WANG ZQ, LI J. (2007) [Loss of imprinting of IGF2 in cord blood of newborns of Chinese Han population]. Zhonghua Yi Xue Yi Chuan Xue Za Zhi 24:10-14

DAVIES SM. (1994) Developmental regulation of genomic imprinting of the IGF2 gene in human liver. Cancer Res 54:2560-2562

DOUC-RASY S, BARROIS M, FOGEL S, AHOMADEGBE JC, STEHELIN D, COLL J, RIOU G. (1996) High incidence of loss of heterozygosity and abnormal imprinting of H19 and IGF2 genes in invasive cervical carcinomas. Uncoupling of H19 and IGF2 expression and biallelic hypomethylation of H19. Oncogene 12:423-430

FU VX, DOBOSY JR, DESOTELLE JA, ALMASSI N, EWALD JA, SRINIVASAN R, BERRES M, SVAREN J, WEINDRUCH R, JARRARD DF. (2008) Aging and cancer-related loss of insulin-like growth factor 2 imprinting in the mouse and human prostate. Cancer Res 68:6797-6802

GAO RF, HE JL, LIU XQ, DING YB, CHEN XM, CHEN Q, TAN Y, WANG YX. (2011) Evaluation of IGF2 imprinting status and the levels of folate biomarkers in second trimester pregnant Chinese women. J Reprod Med 56:254-260

HAJDU M, SINGER S, MAKI RG, SCHWARTZ GK, KEOHAN ML, ANTONESCU CR. (2010) IGF2 over-expression in solitary fibrous tumours is independent of anatomical location and is related to loss of imprinting. J Pathol 221:300-307

HASHIMOTO K, AZUMA C, KOYAMA M, OHASHI K, KAMIURA S, NOBUNAGA T, KIMURA T, TOKUGAWA Y, KANAI T, SAJI F. (1995) Loss of imprinting in choriocarcinoma. Nat Genet 9:109-110

HONDA S, ARAI Y, HARUTA M, SASAKI F, OHIRA M, YAMAOKA H, HORIE H, NAKAGAWARA A, HIYAMA E, TODO S, KANEKO Y. (2008) Loss of imprinting of IGF2 correlates with hypermethylation of the H19 differentially methylated region in hepatoblastoma. Br J Cancer 99:18911899

KALSCHEUER VM, MARIMAN EC, SCHEPENS MT, REHDER H, ROPERS HH. (1993) The insulin-like growth factor type-2 receptor gene is imprinted in the mouse but not in humans. Nat Genet 5:74-78 
KANEDA A, WANG CJ, CHEONG R, TIMP W, ONYANGO P, WEN B, IACOBUZIO-DONAHUE CA, OHLSSON R, ANDRAOS R, PEARSON MA, SHAROV AA, LONGO DL, KO MS, LEVCHENKO A, FEINBERG AP. (2007) Enhanced sensitivity to IGF-II signaling links loss of imprinting of IGF2 to increased cell proliferation and tumor risk. Proc Natl Acad Sci U S A 104:20926-20931

MARTIN-TRUJILLO A, VAN RIETSCHOTEN JG, TIMMER TC, RODRIGUEZ FM, HUIZINGA TW, TAK PP, MARSAL S, IBRAHIM SM, DIJKMANS BA, VAN DER POUW KRAAN TC, VERWEIJ CL. (2010) Loss of imprinting of IGF2 characterises high IGF2 mRNA-expressing type of fibroblast-like synoviocytes in rheumatoid arthritis. Ann Rheum Dis 69:1239-1242

MICHA AE, HAHNEL S, FRIESS H, BUCHLER MW, ADLER G, GRESS TM. (1999) Genomic imprinting of IGF-II and H19 in adult human pancreatic tissues. Digestion 60:477-483

MULLER S, ZIRKEL D, WESTPHAL M, ZUMKELLER W. (2000) Genomic imprinting of IGF2 and H19 in human meningiomas. Eur J Cancer 36:651-655

NAEVE GS, VANA AM, EGGOLD JR, VERGE G, LING N, FOSTER AC. (2000) Expression of rat insulin-like growth factor binding protein-6 in the brain, spinal cord, and sensory ganglia. Brain Res Mol Brain Res 75:185-197

OGAWA O, ECCLES MR, SZETO J, MCNOE LA, YUN K, MAW MA, SMITH PJ, REEVE AE. (1993) Relaxation of insulin-like growth factor II gene imprinting implicated in Wilms' tumour. Nature 362:749-751

ROY RN, GERULATH AH, CECUTTI A, BHAVNANI BR. (2000) Loss of IGFII imprinting in endometrial tumors: overexpression in carcinosarcoma. Cancer Lett 153:67-73

SHI W, KRELLA A, ORTH A, YU Y, FUNDELE R. (2005) Widespread disruption of genomic imprinting in adult interspecies mouse (Mus) hybrids. Genesis 43:100-108

SUZUKI H, UEDA R, TAKAHASHI T. (1994) Altered imprinting in lung cancer. Nat Genet 6:332-333

TAKEDA S, KONDO M, KUMADA T, KOSHIKAWA T, UEDA R, NISHIO $\mathrm{M}$, OSADA H, SUZUKI H, NAGATAKE M, WASHIMI O, TAKAGI K,
TAKAHASHI T, NAKAO A. (1996) Allelic-expression imbalance of the insulin-like growth factor 2 gene in hepatocellular carcinoma and underlying disease. Oncogene 12:1589-1592

VAN GURP RJ, OOSTERHUIS JW, KALSCHEUER V, MARIMAN EC, LOOIJENGA LH. (1994) Biallelic expression of the H19 and IGF2 genes in human testicular germ cell tumors. J Natl Cancer Inst 86:1070-1075

VU TH, HOFFMAN AR. (1994) Promoter-specific imprinting of the human insulin-like growth factor-II gene. Nature 371:714-717

VU TH, NGUYEN AH, HOFFMAN AR. (2010) Loss of IGF2 imprinting is associated with abrogation of long-range intrachromosomal interactions in human cancer cells. Hum Mol Genet 19:901-919

WANG WH, DUAN JX, VU TH, HOFFMAN AR. (1996) Increased expression of the insulin-like growth factor-II gene in Wilms' tumor is not dependent on loss of genomic imprinting or loss of heterozygosity. J Biol Chem 271:27863-27870

WANG ZQ, FUNG MR, BARLOW DP, WAGNER EF. (1994) Regulation of embryonic growth and lysosomal targeting by the imprinted Igf2/Mpr gene. Nature 372:464-467

WATERLAND RA, LIN JR, SMITH CA, JIRTLE RL. (2006) Post-weaning diet affects genomic imprinting at the insulin-like growth factor 2 (Igf2) locus. Hum Mol Genet 15:705-716

WU MS, WANG HP, LIN CC, SHEU JC, SHUN CT, LEE WJ, LIN JT. (1997) Loss of imprinting and overexpression of IGF2 gene in gastric adenocarcinoma. Cancer Lett 120:9-14

XU W, FAN H, HE X, ZHANG J, XIE W. (2006) LOI of IGF2 is associated with esophageal cancer and linked to methylation status of IGF2 DMR. J Exp Clin Cancer Res 25:543-547

YUN K. (1998) Genomic imprinting and carcinogenesis. Histol Histopathol 13:425-435

ZHAN S, SHAPIRO DN, HELMAN LJ. (1994) Activation of an imprinted allele of the insulin-like growth factor II gene implicated in rhabdomyosarcoma. J Clin Invest 94:445-448

ZHAN S, SHAPIRO DN, HELMAN LJ. (1995) Loss of imprinting of IGF2 in Ewing's sarcoma. Oncogene 11:2503-2507 